\title{
PALM OIL REFINERY WASTES TREATMENT
}

\author{
K. K. CHIN ${ }^{1}$ and K. K. WONG ${ }^{2}$ \\ ${ }^{1}$ National University of Singapore, Kent Ridge, Singapore 5, Singapore and \\ ${ }^{2}$ Universiti Pertanian Malaysia Serdang. Selangor, Malaysia
}

(Receited October 1980)

\begin{abstract}
Effluent from the refining of crude palm oil was subjected to physical-chemical and biological treatment. An inclined corrugated parallel plates oil separator spaced at $25 \mathrm{~mm}$ was used with hydraulic loading rates of $0.2,0.5$ and $1 \mathrm{~m}^{3} \mathrm{~m}^{-2}-\mathrm{h} .91^{\circ}$ o oil and grease removal could be achieved at $0.2 \mathrm{~m}^{3} \mathrm{~m}^{-2}-\mathrm{h}$. Coagulation and flocculation carried out on batch samples after oil and grease separation revealed that with $100 \mathrm{mgl}^{-1}$ alum addition BOD was reduced from 3500 to $450 \mathrm{mgl}^{-1}$ and COD from 8600 to $750 \mathrm{mg} \mathrm{t}^{-1}$ after $30 \mathrm{~min}$ settling. Higher doses of alum and doses of polyelectrolyte, activated carbon and sodium hypochloride did not yield significant additional reductions in BOD and COD. Batch dissolved air flotation (DAF) removed $90^{\circ}$ of the suspended solids with $2.7 \%$ solids in the thickened sludge at an $\mathrm{A} / \mathrm{S}$ ratio of 0.014 . This method yielded the similar effiuent quality as the inclined corrugated plates oil and grease separator. Field data from a DAF plant compare closely with data achieved in this study. Activated sludge treatment on the effluent from the oil separator yielded a BOD of

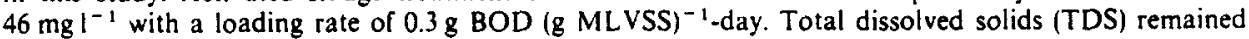
high and removal through coagulation and chemical oxidation brought the COD level down to around $180 \mathrm{mg} \mathrm{l}^{-1}$. Biokinetic coefficients $Y, k_{d}, K$ and $K$, were found to be $0.85 \mathrm{~g}$ VSS (g BOD) $)^{-1}, 0.016$ day $^{-1}$. $\left.0.12 \mathrm{~g} \mathrm{BOD}^{\mathrm{g} \mathrm{VSS}}\right)^{-1}$-day and $510 \mathrm{mg} \mathrm{l}^{-1} \mathrm{BOD}$ respectively.
\end{abstract}

\section{INTRODUCTION}

Edible oil products in Singapore and Malaysia are derived mainly from refining crude palm oil which is a mixture of glyceride esters containing mainly $\mathrm{C}_{16}-\mathrm{C}_{18}$ fatty acids, free glycerine. proteins, and gums (Table 1). The refining process involves the segregation of its constituents by physical and chemical means to produce olein, stearin and acid oils (Fig. 1). Most of the refineries are operating near urban centres or within the drainage area of streams providing potable water supply. The effluent standards for Watercourse in Singapore and Malaysia specify that BOD, COD, total suspended solids, and total oil and grease should not exceed $50,100,50$ and $10 \mathrm{mg} \mathrm{l}^{-1}$ respectively.

An average refinery generates around $400 \mathrm{~m}^{3}$ day ${ }^{-1}$ of wastewaters. Major constituents include alkaline neutralization wash water, soap stock splitting effluent, spent liquor from chemicals and solvent extraction, detergent fractionation blowdown, circuit bleed of cooling water, carrier liquids of unwanted oil frac- tions and spillages, floor wash and equipment cleaning water. The final effluent contains high concentrations of free and dissolved oil and fatty acids. sodium soaps, glycerine, crude oil solids, heavy metals from earth bleaching, ionized caustic soda and sulphuric acids, and detergent such as sodium lauryl sulphate.

Characteristics of the effluent vary widely from day to day and from plant to plant (Table 2). Treatment to meet the effluent standards is complicated. This paper summarizes treatment studies using physicalchemical and biological processes for the wastewater.

\section{MATERIALS AND METHODS}

Samples were collected fresh from the refinery for laboratory scale physical-chemical treatment studies. $\mathrm{pH}$ and temperature of the combined wastes were around 5.0 and $60^{\circ} \mathrm{C}$ respectively. Processes investigated include inclined corrugated parallel plates separation, chemical coagulation and flocculation, and dissolved air flotation. Field data from a 500 tons day ${ }^{-1}$ mill treating around $20 \mathrm{~m}^{3} \mathrm{~h}^{-1}$ refinery effluent using oil and grease separation. coagulation

Table 1. Characteristics of palm oil and fractionated products

\begin{tabular}{lccc}
\hline Fatty acid & Palm oil & $\begin{array}{c}\text { Range } \\
(\%) \\
\text { Palm olein }\end{array}$ & Palm stearin \\
\hline Saturated & & & \\
$\quad$ Lauric & $0.1-0.4$ & $0.1-0.6$ & $0.1-0.4$ \\
Myristic & $0.9-1.4$ & $0.9-1.4$ & $1.1-1.8$ \\
Palmitic & $41.9-46.7$ & $37.9-41.8$ & $46.6-73.8$ \\
Stearic & $4.3-5.1$ & $4.0-4.8$ & \\
Arachidic & $0.3-0.7$ & $0.3-0.8$ & \\
\hline
\end{tabular}




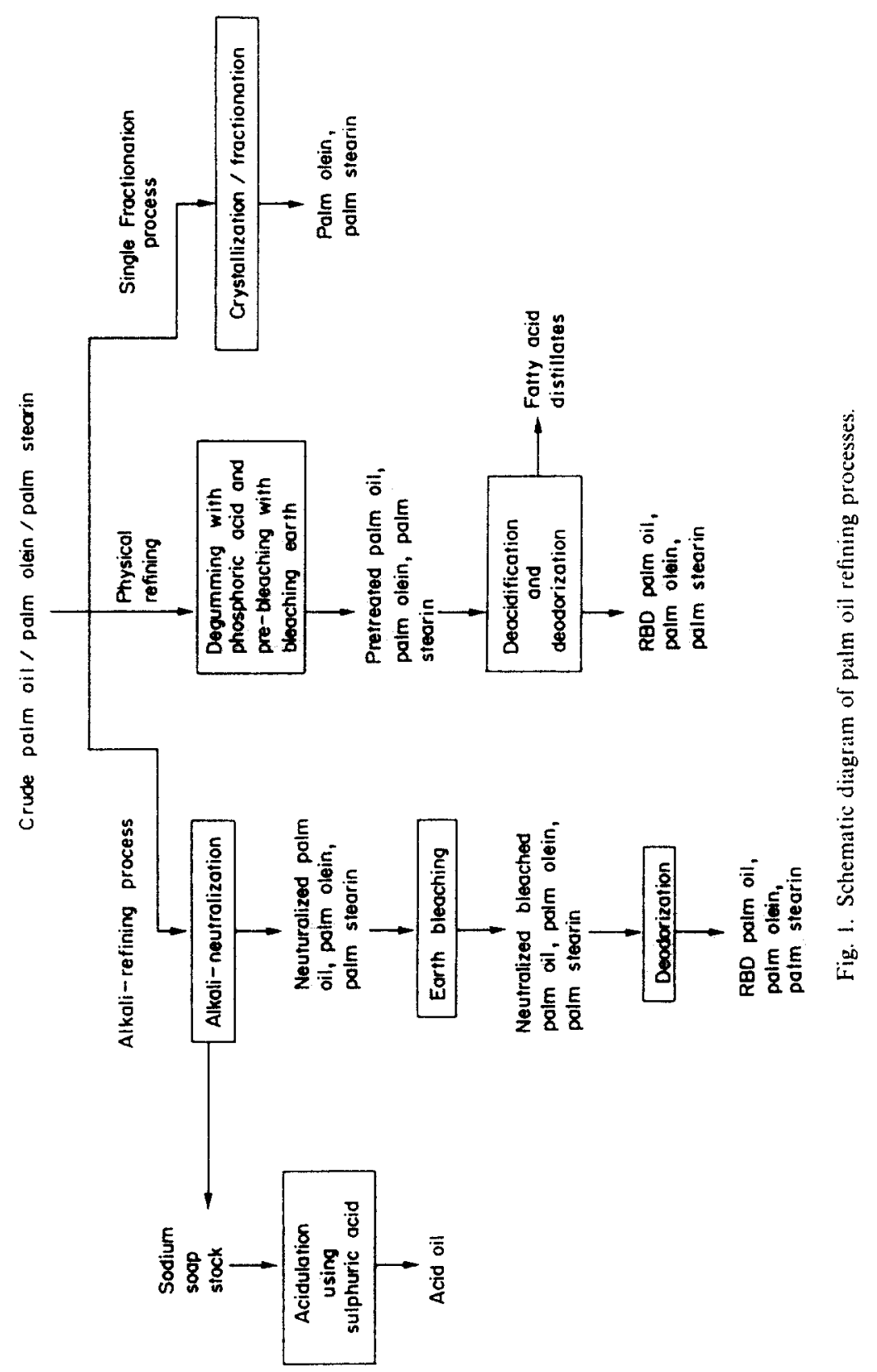


Table 2. Characteristics of palm oil refinery wastes

\begin{tabular}{|c|c|c|}
\hline \multirow[b]{2}{*}{ Parameters } & \multicolumn{2}{|c|}{ Combined wastewater } \\
\hline & Range & Mean \\
\hline Temperature, ${ }^{\mathrm{C}} \mathrm{C}$ & $58-65$ & 60 \\
\hline & $2-6$ & 4.5 \\
\hline BOD, $\mathrm{mg} \mathrm{l}^{-1}$ & $3500-16,000$ & 5000 \\
\hline $\mathrm{COD}, \mathrm{mg} \mathrm{l}^{-1}$ & $6500-32,000$ & 15,000 \\
\hline TDS, $\mathrm{mgl}^{-1}$ & $8700-15,800$ & 9200 \\
\hline TSS $\mathrm{mg} \mathrm{i}^{-1}$ & $3000-12,000$ & 5000 \\
\hline$T P, \mathrm{mg}^{-1}$ & $20-80$ & 60 \\
\hline TKN, $\mathrm{mg} \mathrm{l}^{-1}$ & $30-300$ & 180 \\
\hline Oil and grease, $\mathrm{mg} \mathrm{l}^{-1}$ & $1250-23,800$ & 4230 \\
\hline
\end{tabular}

and flocculation with a polyelectrolyte, and dissolved air flotation were included for comparison with laboratory data.

For biological studies on the composite effluent from physical-chemical treatment, the activated sludge runs were carried out in 50-I. reactors made of perspex sheet and fashioned after a similar continuous feed unit developed by Ludzack (1960). A diffused air system was used to maintain the dissolved oxygen concentration in the mixed liquor at around $\mid \mathrm{mg} \mathrm{|}^{-1}$. The system was started by seeding with activated sludge acclimated cultures from a domestic sewage treatment plant. The progress of the treatment system was monitored at regular intervals for BOD, COD, mixed liquor volatile suspended solids (MLVSS), $\mathrm{pH}$, nitrogen, and phosphate. Specific values of the solids retention time $\theta_{c}$ were estimated by $X /(\Delta X / \Delta t)$, where $X$ is volatile solids in the reactor and $\Delta X / \Delta t$ represents the total volatile solids wasted per day. MLVSS was maintained at relatively constant level $2500 \mathrm{mg} \mathrm{|}^{-1}$ by cell recycling and wasting from the reactor. To ensure that steady-state conditions prevailed, each unit was operated for at least three solids retention times before operational parameters were measured and used in the system analysis.

All physical and chemical analyses were carried out following APHA (1975).

\section{RESULTS AND DISCUSSION}

Three separate runs at $0.2,0.5$ and $1 \mathrm{~m}^{3} \mathrm{~m}^{-2}$-h hydraulic loading rates were carried out for the $25 \mathrm{~mm}$ spacing inclined corrugated parallel plate oil separator. The results of these runs are given in Table 3.

Around $91 \%$ of the oil and grease were removed at a loading rate of $0.2 \mathrm{~m}^{3} \mathrm{~m}^{-2}-\mathrm{h}$. Even at $1.0 \mathrm{~m}^{3} \mathrm{~m}^{-2}-\mathrm{h}$ loading $81 \%$ removal of the oil and grease were achieved. BOD, COD and suspended solids separations at these loading rates were, however, low.

Batch samples after oil and grease separation were treated by chemical coagulation and flocculation using polyelectrolyte and alum. Results of effluent quality analysis after $30 \mathrm{~min}$ settling are given in Table 4.

With doses of $100 \mathrm{mg}^{-1}$ alum, the BOD level was reduced from 3500 to $450 \mathrm{mg} \mathrm{l}^{-1}$ and COD from 8600 to $750 \mathrm{mg}^{-1}$. There were significant reduction in $B O D$ and $C O D$ when alum dose was increased to $200 \mathrm{mg} \mathrm{l}^{-1}$. Above $200 \mathrm{mg} \mathrm{l}^{-1}$ increased alum dose had little effect on COD removal. The addition of polyelectrolyte, activated carbon, and sodium hypochlorite showed little improvement in BOD and COD removal. Results also show considerable variations in treated water quality. The flocs after chemical coagulation and flocculation did not settle well. For effective flocs removal combined sedimentation and flotation units may have to be installed.

Batch dissolved air flotation runs were carried out using an apparatus described by Eckenfelder (1966). The water and air were mixed under pressure for at least $2 \mathrm{~min}$ for dissolution of air into water. Around $20 \mathrm{~min}$ was allowed for solids separation and concentration at atmospheric pressure. Results of the test runs are given in Figs 2 and 3. 90\% removal of the suspended solids with $2.7 \%$ solids in the thickened sludge can be expected using the dissolved air flotation systems for suspended solids removal at an airsolids $(\mathrm{A} / \mathrm{S})$ ratio of 0.014 . The expected effluent COD concentration would be around $800 \mathrm{mg} \mathrm{l}^{-1}$, and oil and grease $20 \mathrm{mg} \mathrm{l}^{-1}$. Dissolved air flotation system operated at $0.014 \mathrm{~A} / \mathrm{S}$ ratio (equivalent gauge pressure $=4 \mathrm{~atm}$ ) thus achieved the same quality effluent as that of a system using corrugated parallel plate separation at $0.2 \mathrm{~m}^{3} \mathrm{~m}^{-2}-\mathrm{h}$ loading rate coupled with plain sedimentation when the same amount of coagulating chemicals were applied. Field data from a full scale dissolved air flotation plant treating around $20 \mathrm{~m}^{3} \mathrm{~h}^{-1}$ of the wastes compare closely with data attained in the laboratory (Table 5).

This plant has been in operation for more than 3 months at a gauge pressure of $6 \mathrm{Bar}$ and chemical dosing rates of 1700 alum and $2.5 \mathrm{mg} \mathrm{l}^{-1}$ polyelectrolyte. Physical-chemical treatment is thus unable to produce an effluent quality meeting the effluent standards.

Activated sludge treatment was carried out using effluent from the oil separator running at $0.2 \mathrm{~m}^{3} \mathrm{~m}^{-2}-\mathrm{h}$. The BOD:N:P ratio after oil separation was around 100:3.6:1.1. Whenever necessary, urea was added as nutrient supplement for continuous bacteria growth in the reactors. Experimental units were set up respectively using loading rates of

Table 3. Corrugated plate treatment data

\begin{tabular}{|c|c|c|c|c|}
\hline & \multirow[b]{2}{*}{ Influent } & \multicolumn{2}{|c|}{ Effluent conc. (mg | ${ }^{-1}$ ) } & \multirow[b]{2}{*}{$1 \mathrm{~m}^{3} \mathrm{~m}^{-2}-\mathrm{h}$} \\
\hline & & $0.2 \mathrm{~m}^{3} \mathrm{~m}^{-2}-\mathrm{h}$ & $0.5 \mathrm{~m}^{3} \mathrm{~m}^{-2}-\mathrm{h}$ & \\
\hline $\mathrm{BOD}, \mathrm{mg} \mathrm{I}^{-1}$ & 5200 & 3500 & 3760 & 3980 \\
\hline $\mathrm{COD}, \mathrm{mg} \mathrm{l}^{-1}$ & 14,800 & 8600 & 9200 & 9800 \\
\hline Oil and grease, $\mathrm{mg} \mathrm{I}^{-1}$ & 4230 & 350 & 886 & 1640 \\
\hline Total suspended solids, $\mathrm{mg} \mathrm{l}^{-1}$ & 4950 & 3200 & 3600 & 3850 \\
\hline
\end{tabular}




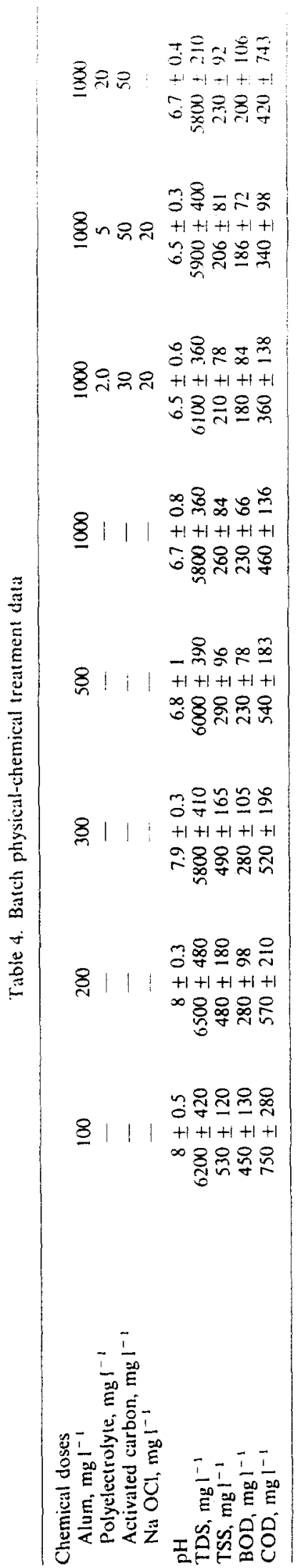

1.23. 0.58 and $0.3 \mathrm{~g}$ BOD per $\mathrm{g}$ MLVSS per day. The MLVSS concentrations of all units were maintained at around $2500 \mathrm{mgl}^{-1}$ through cell recyeling and wasting. The steady state parameters are given in Table 6.

At a loading rate of 0.3 (g BOD) (g MLVSS) ${ }^{-1}$ day. the BOD level was reduced to around $50 \mathrm{mg} \mathrm{l}^{-1}$ which met with the effluent standards. COD remained at relatively high levels. The system. however, was able to maintain a MLVSS level of around $2500 \mathrm{mg} \mathrm{l}^{-1}$ with good settling of the biological flocs. Total dissolved solids remained very high and thus could not be substantially removed by the activated sludge process. Similarly, colour content was high with a value of around 800 Hazen units. High TDS and colour would be a problem for discharge into the receiving waters. Further treatment through coagulation with $200 \mathrm{mg} \mathrm{l}^{-1}$ alum and $50 \mathrm{mg} \mathrm{l}^{-1}$ of activated carbon reduced the COD level to $220 \mathrm{mg} \mathrm{|}^{-1}$ and colour to 680 Hazen units. Chemical oxidation with sodium hypochlorite up to $50 \mathrm{mg} \mathrm{l^{-1 }}$ brought the COD level down to around $180 \mathrm{mg} \mathrm{l}^{-1}$. This was above the allowable values of $100 \mathrm{mg} \mathrm{l}^{-1} \mathrm{COD}$

A rational evaluation of the biokinetics of the activated sludge study based upon Monod's (1949) work was carried out with:

$$
\frac{X}{S_{0}-S}=\frac{K_{s}}{k} \frac{1}{S}+\frac{1}{k}
$$

and

$$
\frac{1}{\theta_{c}}=\frac{Y\left(\mathrm{~S}_{0}-\mathrm{S}\right)}{\theta X}-k_{d}
$$

where $X=$ Microbial mass concentration (measured

$\theta=$ Hydraulic retention time

$\theta_{c}=$ Solids retention time

$S_{0}=$ Influent growth limiting substrate concentration (measured in BOD)

$S=$ Effluent growth limiting substrate concentration

$K_{s}=$ Half-velocity constant

$k=$ Maximum rate of substrate utilization per unit mass of microorganisms

$k_{\mathrm{d}}=$ Endogenous decay coefficient

$Y=$ Maximum yield coefficient

$\theta_{c}^{m}$, the minimum cell retention time is defined as:

$\frac{1}{\theta_{c}^{m}}=\frac{k Y S_{0}}{K_{s}+S_{0}}-k_{d}$

The biokinetics constants $Y, k_{\mathrm{d}}, k$ and $K_{s}$ were determined to be 0.85 (g VSS) $(\mathrm{g} \mathrm{BOD})^{-1}, 0.016$ day $^{-1}$ 0.12 (g BOD) (g VSS) ${ }^{-1}$-day and $510 \mathrm{mg} \mathrm{l}^{-1}$ BOD respectively. These values were not significantly different from biokinetics evaluated for raw palm oil sludge (Chin, 1978). The minimum cell residue time $\theta_{c}^{m}$ was determined to be around 13 days. 


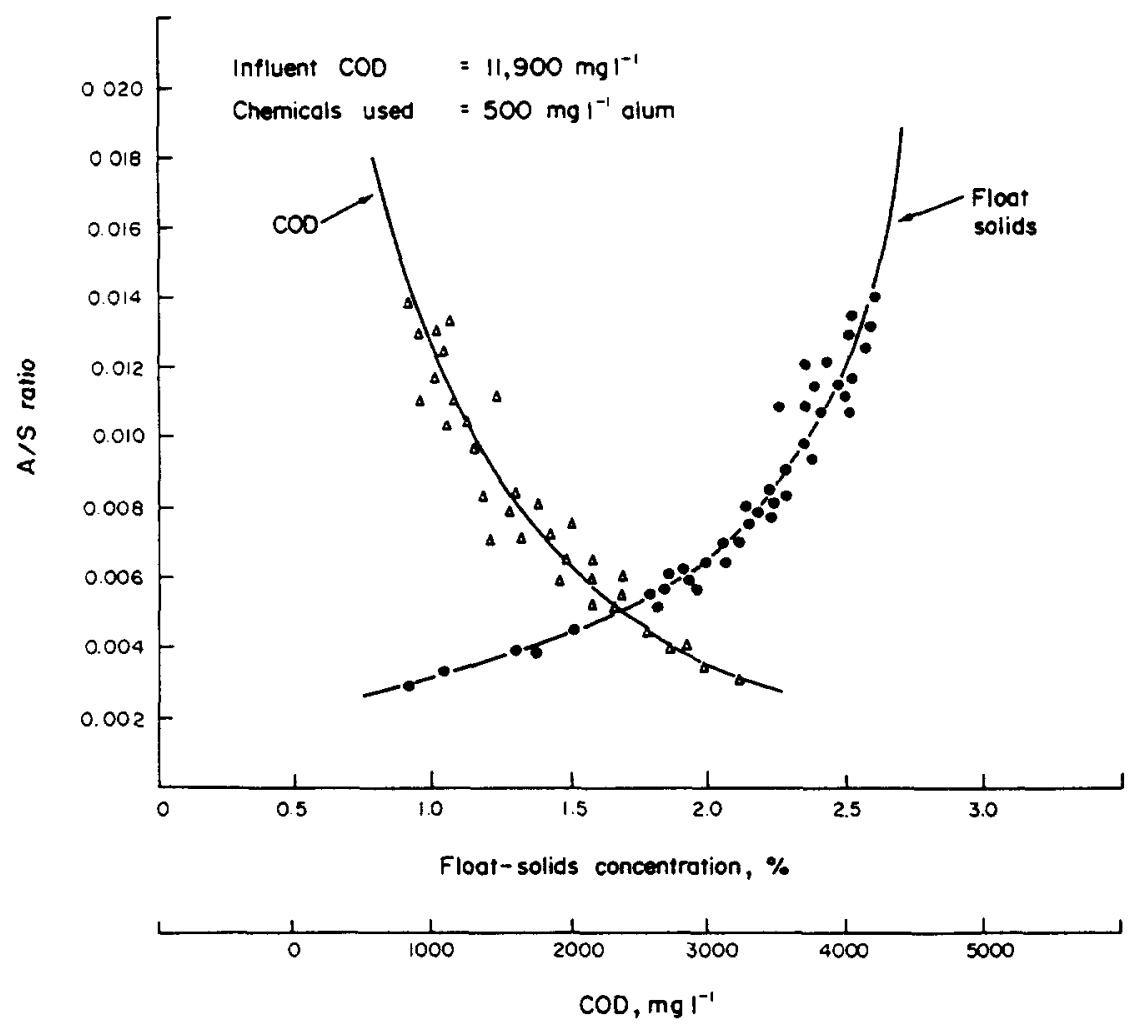

Fig. 2. Relationship between $\mathrm{A} / \mathrm{S}$ ratio, foat solids and COD.

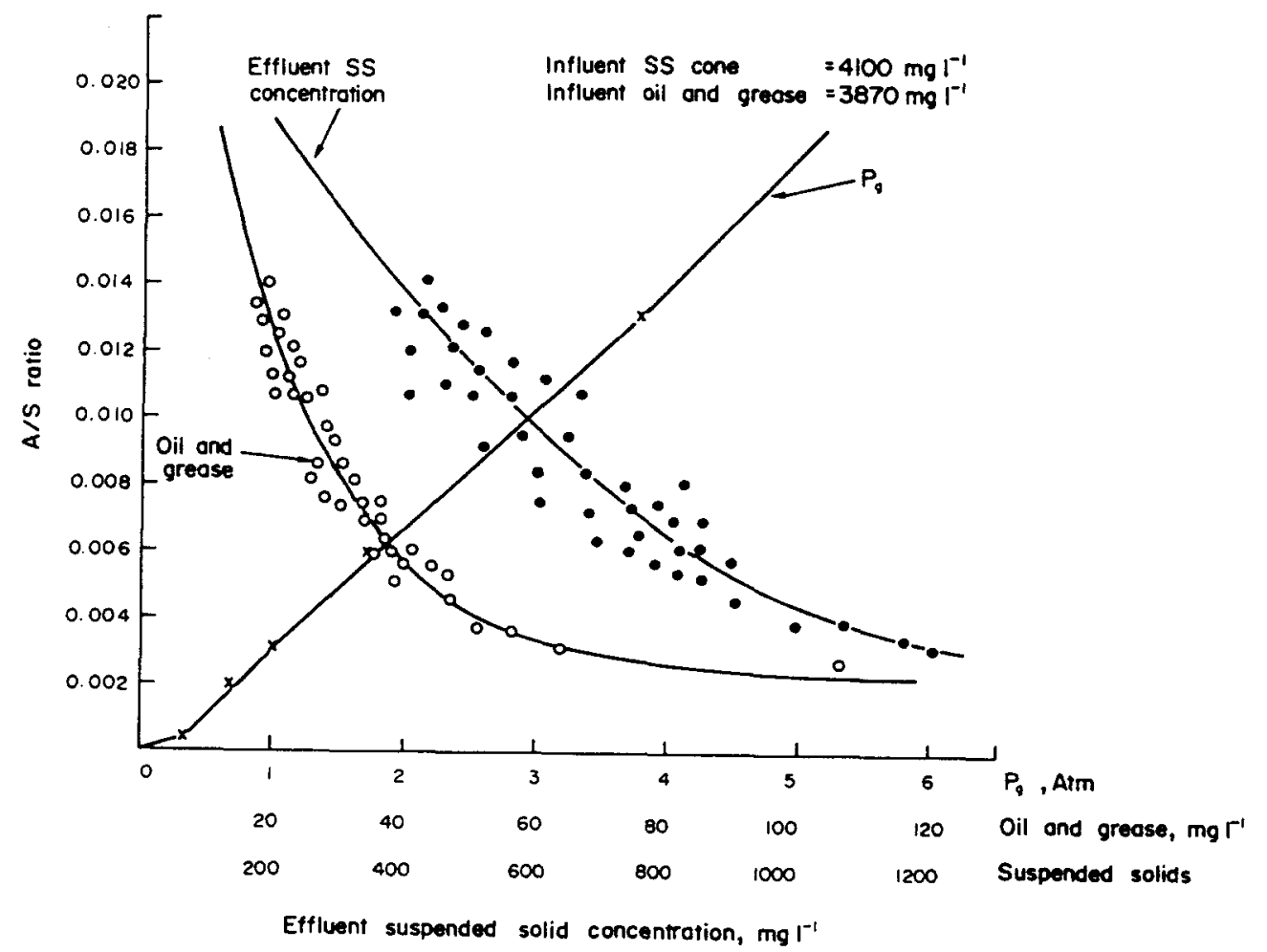

Fig. 3. Relationship between $\mathrm{A} / \mathrm{S}$ ratio. SS concentration and oil and grease. 
Table 5. Effluent quality from full scale plant (Sorenson \& Dencker, 1980)

\begin{tabular}{|c|c|c|c|}
\hline & Influent & Effluent & $\begin{array}{c}\text { Ave. } \\
\text { removal } \\
\text { (D) }\end{array}$ \\
\hline $\mathrm{BOD}, \mathrm{mg}^{-\mathrm{t}}$ & $6000-15.000$ & $780-2020$ & 89.6 \\
\hline $\mathrm{COD}, \mathrm{mg} \mathrm{l}^{-\mathrm{i}}$ & $6670-35,200$ & $890-6560$ & 89.1 \\
\hline Oil and grease, $\mathrm{mg} \mathrm{l}^{-1}$ & $2010-9210$ & $6.5-23.5$ & 99.7 \\
\hline Suspended solids, $\mathrm{mg} \mathrm{l}^{-1}$ & $2350-9810$ & $45-350$ & 97.4 \\
\hline $\mathrm{pH}$ & $2.1-3.0$ & 6 & $\ldots$ \\
\hline
\end{tabular}

Table 6. Steady state operating parameters

\begin{tabular}{|c|c|c|c|}
\hline$\theta$, days & 1 & 2.5 & 5 \\
\hline $\begin{array}{l}\text { Loading rates } \\
\qquad \mathrm{g} \mathrm{BOD} \mathrm{(g} \mathrm{MLVSS)})^{-1} \\
\text { g COD (g MLVSS) }\end{array}$ & $\begin{array}{l}1.23 \\
3.03\end{array}$ & $\begin{array}{l}0.58 \\
1.42\end{array}$ & $\begin{array}{l}0.30 \\
0.73\end{array}$ \\
\hline $\begin{array}{l}\text { Settled effluent } \\
\text { BOD, } \mathrm{mg} \mathrm{l}^{-1} \\
\text { COD, } \mathrm{mg} \mathrm{l}^{-1} \\
\text { SS, mg l-1 }\end{array}$ & $\begin{array}{r}580 \\
1200 \\
230\end{array}$ & $\begin{array}{l}280 \\
740 \\
110\end{array}$ & $\begin{array}{r}46 \\
380 \\
68\end{array}$ \\
\hline $\begin{array}{l}\text { MLVSS, mg } \mathrm{l}^{-1} \\
\mathrm{pH} \\
\text { Colour, Hazen units } \\
\text { TDS, mg l-1 } \\
\text { SVI } \\
\theta_{c} \text {, day } \\
\text { F/M BOD basis } \\
\text { Oil and grease, } \mathrm{mg} \mathrm{l}^{-1} \\
\text { Waste sludge, g day }\end{array}$ & $\begin{array}{c}2840 \\
7.8 \\
870 \\
5800 \\
150 \\
15 \\
1.36 \\
12 \\
9.47\end{array}$ & $\begin{array}{c}2430 \\
7.8 \\
740 \\
5400 \\
80 \\
28 \\
0.58 \\
11.2 \\
4.34\end{array}$ & $\begin{array}{c}2360 \\
7.8 \\
790 \\
5600 \\
80 \\
45 \\
0.30 \\
10.6 \\
2.62\end{array}$ \\
\hline
\end{tabular}

\section{CONCLUSION}

Palm oil refineries generate a wastewater which is high in organics and solids. An inclined plate oil separator removed more than $90 \%$ of the oil and grease and $30 \%$ of the BOD. With doses of $1000 \mathrm{mg} \mathrm{l}^{-1}$ alum and $2.0 \mathrm{mg} \mathrm{1}^{-1}$ polyelectrolyte, and $50 \mathrm{mg} \mathrm{I}^{-1}$ activated carbon, BOD and COD were brought down to 200 and $420 \mathrm{mg} \mathrm{l}^{-1}$ respectively. Dissolved air flotation removed more than $90 \%$ of the oil and grease and produced an effluent quality similar to a system using corrugated parallel plate separation followed by sedimentation after chemical coagulation and flocculation. Full scale plant operation data agree well with laboratory dissolved air flotation runs. Activated sludge treatment on the physical-chemical treated effluent at $0.3 \mathrm{~g}$ BOD (g MLVSS) ${ }^{-1}$-day reduced the $B O D$ concentration level to $46 \mathrm{mg} \mathrm{l}^{-1}$ and $C O D$ to $380 \mathrm{mg} \mathrm{l}^{-1}$. Colour and total dissolved solids remained high at around 790 Hazen units and $5600 \mathrm{mg} \mathrm{l}^{-1}$ respectively. Further treatment of the activated sludge effluent with alum, carbon adsorption and sodium hypochlorite oxidation, brought the COD level down to only $180 \mathrm{mg} \mathrm{|}^{-1}$.

\section{REFERENCES}

APHA (1975) Standard Methods for the Examination of Water and Wastewater, 14th Edition. American Water Work Association. American Public Health Association. Washington, DC.

Chin K. K. (1978) Palm oil waste treatment by aerobic process. Proc. International Conference on Warer Pollution Control in Developing Countries, Bangkok. Thailand. Eckenfelder W. W. (1960) Industrial Water Pollution Control. McGraw-Hill, New York.

Ludzack F. J. (1960) Laboratory model activated sludge unit. J. Wat. Pollut. Control Fed. 32, 605.

Monod J. (1949) The growth of bacterial cultures. A. Rer. Microbiol. 3, 371 .

Sorenson P. B. \& Dencker E. (1980) Palm oil refinery waste treatment applying the aminodan system. Proc. Symposium on Industrial Wastewater Control, Universiti Pertanian Malaysia, Serdang, Malaysia. 